RAP CONFERENCE PROCEEDINGS, VOL. 5, PP. 68-71, 2020

ISSN 2737-9973 (ONLINE)| DOI: 10.37392/RAPPROC.2020.16

RAP-PROCEEDINGS.ORG

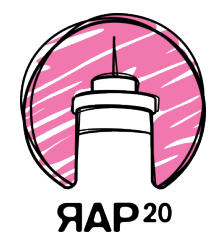

\title{
DOSE ADJUSTMENT TO ENSURE UNIFORMITY OF CYLINDRICAL FOODSTUFF IRRADIATION
}

\author{
F. Studenikin ${ }^{1^{*}}$, U. Bliznyuk', G. Krusanov ${ }^{2}$, A. Chernyaev', \\ V. Khankin', P. Borschegovskaya', V. Ipatova', A. Bliznyuk ${ }^{4}$
}

\author{
${ }^{1}$ Lomonosov Moscow State University, Physics Department, Moscow, Russian Federation \\ ${ }^{2}$ Burnasyan Federal Medical Biophysical Center of Federal Medical Biological Agency, Moscow, Russian Federation \\ 3Scientific Institute of Nuclear Physics named by D.V. Skobeltcin, Moscow, Russian Federation \\ 4Lyceum School \#2, Moscow, Russian Federation
}

\begin{abstract}
This study focuses on achieving a higher uniformity of $10 \mathrm{MeV}$ electron treatment of cylindrical products by including aluminum modifiers of different thicknesses in the irradiation scheme. It was simulated the irradiation of cylindrical water phantom by beams of accelerated electrons with an energy of $10 \mathrm{MeV}$ from two opposite sides using GEANT 4. During the simulation, aluminum plates-modifiers of different thicknesses of 1, 1.5 and $2 \mathrm{~mm}$ were added between the cylindrical phantom and the beam output in order to assess dose uniformity inside the phantom. It was found that the higher the thickness of aluminum plates, the more uniformity could be achieved. While $1 \mathrm{~mm}$ and $1.5 \mathrm{~mm}$ plates enable the efficiency ratio of $30 \%$ and $45 \%$, respectively, a $2 \mathrm{~mm}$ modifier increases the uniformity of irradiation up to $60 \%$. In this way, computer modeling proves that inserting beam plates-modifiers between irradiated samples and beam output for irradiation from two opposite sides allows to considerably increase the uniformity of sample irradiation with complex geometry.
\end{abstract}

Keywords: Foodstuff irradiation, dose distribution, uniformity irradiation, beam modifiers

\section{INTRODUCTION}

Food safety is a major concern these days with the increase in a number of consumers across the world and frequent cases of food poisoning as a result of improper handling of products. The modern trend of convenience food calls for treatment methods that would ensure human health and environmental safety while extending the shelf life of processed and prepackaged foods [1-3].

While irradiation processing has proved to be the most efficient method that allows to achieve the desired properties of foodstuff for long-term storage, now the researchers are refining the irradiation parameters to achieve a uniform and stable result which can be replicated on a wider variety of products. The application of cutting-edge accelerators and new simulation methods has turned into reality irradiation treatment of foods with complex geometry.

It has been established by the World Health Organization that foods irradiated with the doses of up to $10 \mathrm{kGy}$ are suitable for consumption [4]. While the doses specified in the international regulations cover all types of foodstuffs, some adjustments are required for certain categories of products to achieve the desired result. The acceptable dose range varies from product to product [1-7]. It is just as important not to go below the lower limit as not to exceed the upper limit. If the dose is lower than acceptable, it will not inhibit the growth of pathogens for the extended period of time, while exceeding the upper limit will cause undesirable changes in the properties of treated product [8-15].

Since both food industry and radiation treatment centers seek to increase the volume of irradiated products, the use of electron accelerators in industrial treatment of foodstuff is becoming a common trend [16-19].

At the same time, food radiation focuses on achieving greater uniformity of exposure, which represents a challenge for researchers, who are faced with the need to align the performance of the accelerator to meet the requirements of the diverse market of foods ranging in geometry and texture. Another factor which makes it difficult to ensure irradiation uniformity throughout the product is the layout of items in the package. While it is easy to achieve uniform irradiation of loose products, such as flour or spices, food items of varied texture put together in one package require a much more stringent control of dose exposure within a specified narrow range. Moreover, nonlinear character of the dose distribution curve throughout the product due to a small value of effective electron pass makes it increasingly difficult to achieve irradiation uniformity. This is the case with foods of complex geometry, such as cylindrical or spherical items. Such limitations cause food manufacturers to refrain from irradiating a range

* f.studenikin@gmail.com 
of foodstuff for fear of failure to preserve the original properties of products.

To expand the range of foodstuffs which can be successfully irradiated for a longer shelf life, it is suggested to place beam modifiers of different configuration between the beam output and the product to adjust the electron spectrum and thereby achieve the dose uniformity throughout the product. Beam modifiers are implements that consist of one or several plates made of different materials and their configuration is determined by a computer simulation taking into account physical and technical properties of beam sources as well as characteristics of the product. Electrons with the energy of up to $10 \mathrm{MeV}$ incur ionization losses which alter the initial electron spectrum, causing dose distribution throughout the product to change, as well.

These days, there is an increasing demand in irradiation treatment of processed foods such as sausages, ham, different canned foods and preserves in a cylindrical package. This package shape prevents the substance from uniform irradiation during the conventional treatment. The absorbed dose in the cross section may vary 5 times depending on the value of beam energy, irradiation method as well as the diameter of the cylindrical product.

The acceptable dose range for irradiation treatment of meat and fish products is from $1 \mathrm{kGy}$ to $2 \mathrm{kGy}$ depending on the type of product, and the difference in dose values in cross sections should not be more than 2 times [14]. It is suggested to place aluminum plates of different thickness between the beam output and the cylindrical product to achieve a higher uniformity of irradiation treatment.

The purpose of the study is to achieve a higher uniformity of electron treatment of cylindrical products in simulation by including aluminum modifiers of different thicknesses in the irradiation scheme.

\section{MATERIALS AND METHODS}

For the purpose of the experiment, we used a $10 \mathrm{MeV}$ industrial electron accelerator with a scanning beam and the average power of $15 \mathrm{~kW}$ which was installed at the Russian Irradiation Center Tecleor. Electron energy varies from $5 \mathrm{MeV}$ to $9.5 \mathrm{MeV}$. A high frequency of scanning ensures the uniformity of beam distribution across the scanned area [20].

The parameters of the beam modifier as well as dose distribution values were calculated using a computer simulation based on the Monte-Carlo method. Source code GEANT 4 used in experiments was developed in CERN especially for simulation of physical processes behind irradiation [21-22].

The scanning beam was simulated as the $8 \mathrm{~cm} \times 12 \mathrm{~cm}$ rectangular beam. We used a cylindrical phantom, with the diameter of $7.5 \mathrm{~cm}$ and the length of $11 \mathrm{~cm}$, consisting of the muscle tissue with the density of $0.95 \mathrm{~g} / \mathrm{cm}^{3}$ whose properties were established as per NIST "G4_MUSCLE_STRIATED_ICRU" database.
During the simulation, $2 \times 10^{9}$ electrons, with the spectrum corresponding to that of the industrial accelerator, irradiated the phantom from two opposite sides along the $\mathrm{X}$ axis (Figure 1 ).

Cylindrical objects with the diameter exceeding $6 \mathrm{~cm}$ should be irradiated from two opposite sides with the maximum effective energy since the effective pass of $10 \mathrm{MeV}$ electrons is less or equal to $6 \mathrm{~cm}$ and the density and the composition of the muscle tissue and water are practically the same.

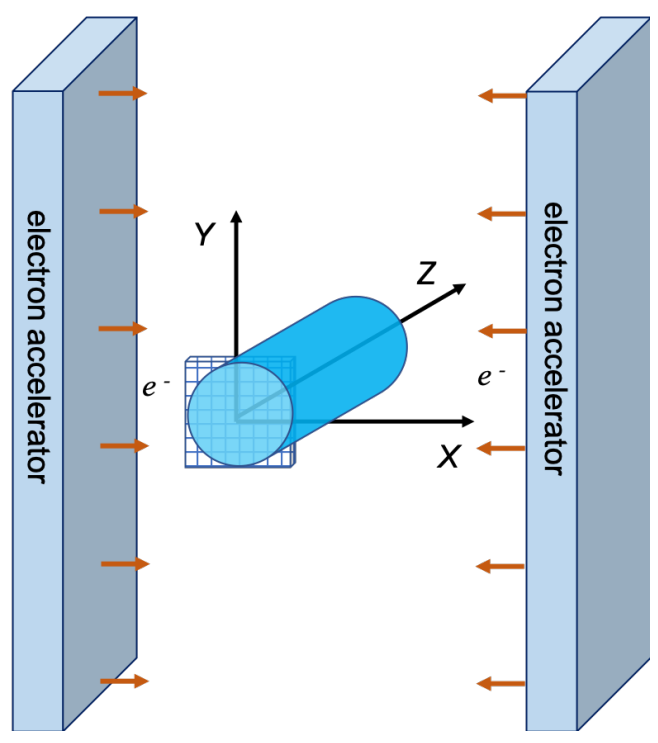

Figure 1. Irradiation treatment of cylindrical products

\section{RESULTS}

Figure 2 shows the relative dose distribution in the cross section of the cylindrical phantom with the coordinates: $5 \mathrm{~mm}<\mathrm{X}<75 \mathrm{~mm}, 5 \mathrm{~mm}<\mathrm{Y}<75 \mathrm{~mm}$, $\mathrm{Z}=1 \mathrm{~mm}$. Dmin/Dmax is the ratio of the minimum dose value to the maximum dose value in the crosssection of a cylindrical phantom.

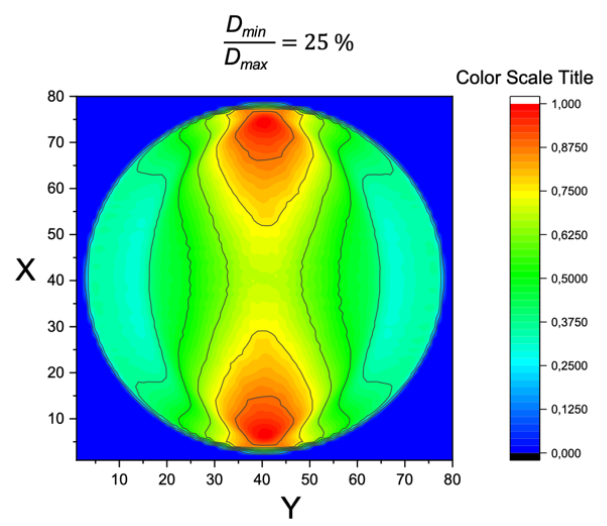

Figure 2. Relative dose distribution in the cross section of a cylindrical phantom 
As it can be seen, cross sections with the coordinates $30 \mathrm{~mm}<\mathrm{X}<50 \mathrm{~mm}$, $5 \mathrm{~mm}<\mathrm{Y}<30 \mathrm{~mm}$ and $50 \mathrm{~mm}<\mathrm{Y}<75 \mathrm{~mm}$; $\mathrm{O} \mathrm{mm}<\mathrm{Z}<110 \mathrm{~mm}$ were overexposed compared to other cross sections. A two-side direct treatment of the phantom fails to enable the required uniformity of irradiation, with the efficiency ratio not higher than $25 \%$.

A much higher uniformity was achieved using aluminum plates of different thickness placed between the cylindrical phantom and the beam output.
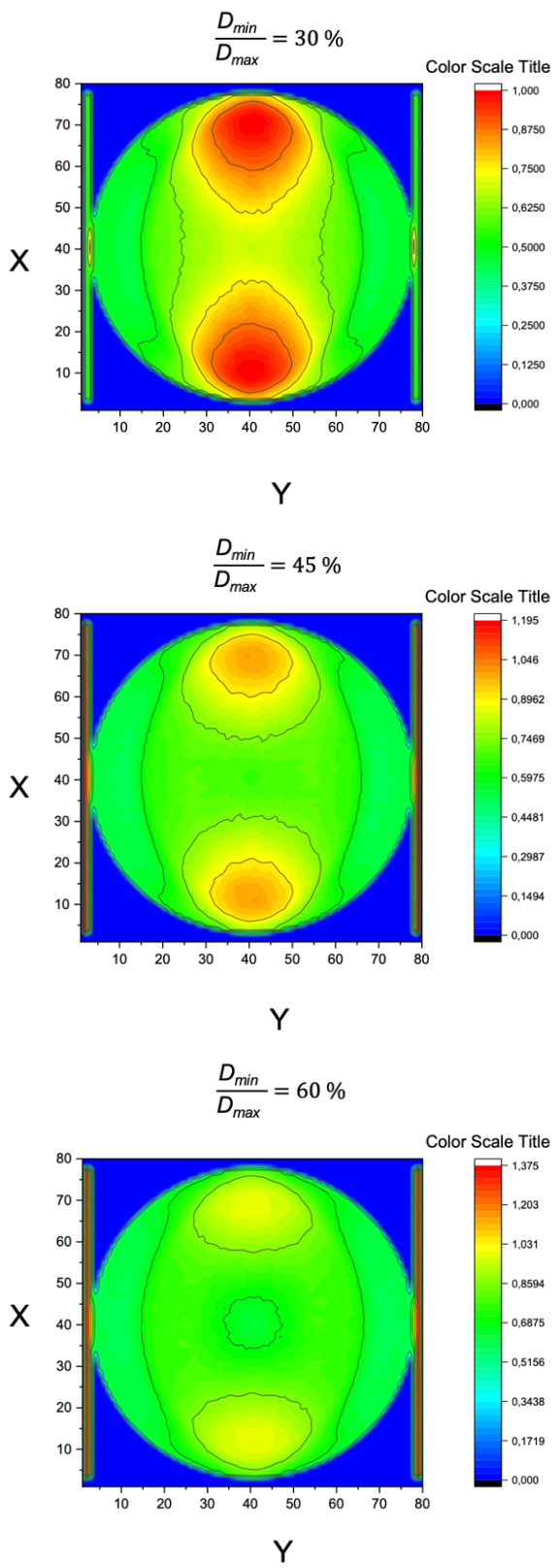

Figure 3. Relative dose distribution in the cross section of a cylindrical phantom adding Al plates of different thickness: a) $1 \mathrm{~mm}$; b) $1.5 \mathrm{~mm}$; c) $2 \mathrm{~mm}$
Figure 3 (a,b,c) shows relative dose distributions in the cross section of the phantom with the coordinates: $5 \mathrm{~mm}<\mathrm{X}<75 \mathrm{~mm}, 5 \mathrm{~mm}<\mathrm{Y}<75 \mathrm{~mm}, \mathrm{Z}=1 \mathrm{~mm}$ using $\mathrm{Al}$ modifiers with the thickness of $1 \mathrm{~mm}, 1.5 \mathrm{~mm}$ and $2 \mathrm{~mm}$.

As it can be seen, the higher the thickness of $\mathrm{Al}$ plates, the more uniformity can be achieved. While $1 \mathrm{~mm}$ and $1.5 \mathrm{~mm}$ plates enable the efficiency ratio of $30 \%$ and $45 \%$, respectively, a $2 \mathrm{~mm}$ modifier increases the uniformity of irradiation up to $60 \%$.

\section{CONCLUSION}

Computer modeling proves that inserting beam modifiers between irradiated samples and beam output for irradiation from two opposite sides allows to considerably increase the uniformity of sample irradiation with complex geometry. Thus, using a $2 \mathrm{~mm} \mathrm{Al}$ plate during the irradiation of a cylindrical phantom of $7.5 \mathrm{~cm}$ in diameter increases the dose efficiency ratio up to $60 \%$ compared with the direct treatment, which ensures the ratio of around $25 \%$.

This approach, based on the Monte-Carlo method, allows to determine the optimal geometry of modifiers to achieve the required dose uniformity in the product of any configuration and composition. The algorithm used takes into account physical and technical characteristics of irradiation sources and treated products.

Currently, the study is purely analytical and we have prepared a set of modifiers which are going to be used in the treatment of cylindrical objects of different diameter and composition in industrial conditions.

\section{REFERENCES}

1. A. P. Chernyaev, S. M. Varzar, A. V. Belousov, M. V. Zheltonozhskaya, E. N. Lykova, "Prospects of development of radiation technologies in Russia," Phys. At. Nucl., vol. 82, no. 5, pp. 513 - 527, Sep. 2019. DOI: $10.1134 / \mathrm{S} 1063778819040070$

2. А.С. Алимов, Практическое применение электронных ускорителей, но. 2011 - 13/877, НИИЯФ МГУ, Москва, Россия, 2011.

(A.S. Alimov, The practical use of electronic accelerators, no. $2011-13 / 877$, MSU SINP, Moscow, Russia, 2011.)

Retrieved from:

http://www.sinp.msu.ru/en/preprint/8278 Retrieved on: Jan. 13, 2019

3. Радиационные технологии. Наука. Народное хозяйство. Медицина, А. П. Черняев, Ред., Москва, Россия: Издательство Московского университета, 2019.

(Radiation technologies. The science. National economy. Medicine, A. P. Chernyaev, Eds., Moscow, Russia: Moscow University Press, 2019.)

Retrieved from:

http://hea.phys.msu.ru/static/data/Chernyaev Radiac tiveTech.pdf

Retrieved on: May 10, 2019

4. Statement summarising the Conclusions and Recommendations from the Opinions on the Safety of 
Irradiation of Food adopted by the BIOHAZ and CEF Panels, Statemen of EFSA, EFSA, Parma, Italy, 2011. Retrieved from:

https://www.efsa.europa.eu/en/efsajournal/pub/2107 Retrieved on: Mar. 29, 2011

5. General Standard for Irradiated Foods, CXS 106-1983, FAO/WHO, Rome, Italy, 2003.

Retrieved from:

http://www.fao.org/fao-who-codexalimentarius/codextexts/list-standards/en/

Retrieved on: Oct. 19, 2018

6. U. A. Bliznyuk et al., "Innovative approaches to developing radiation technologies for processing biological objects," Bull. Russ. Acad. Sci.: Phys., vol. 82, no. 6, Moscow, Russia, Jun. 2018. DOI: $10.3103 / \mathrm{S} 1062873818060072$

7. Радиационные технологии в сельском хозяйстве и пищевой промышленности, Г. В. Козьмин, С. А. Гераськин, Н. И. Санжарова, Ред., Обнинск, Россия: ВНИИРАЭ, 2015.

(Radiation Technologies in Agriculture and Food Industry, G. V. Kozmin, S. A. Geraskin, N. I. Sanzharova, Eds., Obninsk, Russia: RIRAE, 2015.) Retrieved from:

https://www.studmed.ru/kozmin-g-v-geraskin-s-asanzharova-n-i-red-radiacionnye-tehnologii-v-selskomhozyaystve-i-pischevoypromyshlennosti_c5d41bf704e.html

Retrieved on: Oct. 10, 2019

8. S. Y. Lee et al., "Combined Effect of Kimchi Powder and Onion Peel Extract on Quality Characteristics of Emulsion Sausages Prepared with Irradiated Pork," Korean J. Food Sci. Anim. Resour., vol. 35, no. 3, pp. $277-285$, Jun. 2015.

DOI: $10.5851 /$ kosfa.2015.35.3.277

PMid: 26761840

PMCid: PMC4662349

9. S. Ayari, J. Han, K. D. Vu, M. Lacroix, "Effects of gamma radiation, individually and in combination with bioactive agents, on microbiological and physicochemical properties of ground beef," Food Control, vol. 64, pp. 173 - 180, Jun. 2016. DOI: 10.1016/j.foodcont.2015.12.034

10. S. Cheng et al., "The effects of electron beam application on the microbiological stability and physical-chemical quality of mince beef (M. longissimus Dorsi) during cold storage," J. Food Process. Preserv., vol. 42, no. 2, 2018.

DOI: 10.1111/jfpp.13448

11. C. Li et al., "Effect of different irradiation dose treatment on the lipid oxidation, instrumental color and volatiles of fresh pork and their changes during storage," Meat Sci., vol. 128, pp. 68 - 76, Jun. 2017. DOI: 10.1016/j.meatsci.2017.02.009 PMid: 28214694
12. S. A. Bhoir, M. Jhaveri, S. P. Chawla, "Evaluation and predictive modeling of the effect of chitosan and gamma irradiation on quality of stored chilled chicken meat," J. Food Process Eng., vol. 42, no. 6, Sep. 2019. DOI: $10.1111 /$ jfpe.13254

13. A. G. Barroso, N. L. Mastro, "Physicochemical characterization of irradiated arrowroot starch," Radiat. Phys. Chem., vol. 158, pp. 194 - 198, May 2019. DOI: 10.1016/j.radphyschem.2019.02.020

14. A. P. Chernyaev et al., "Study of the Effectiveness of Treating Trout with Electron Beam and X-Ray Radiation," Bull. Russ. Acad. Sci.: Phys., vol. 84, no. 4, Moscow, Russia, Apr. 2020. DOI: $10.3103 / \mathrm{S} 106287382004005 \mathrm{X}$

15. A. P. Chernyaev et al., "Modeling of electron irradiation treatment on kinetics of bacterial content in minced fish," Memoirs of the Faculty of Physics, Lomonosov Moscow State University, no. 2, Moscow, Russia, 2020. Retrieved from: http://uzmu.phys.msu.ru/abstract/2020/2/2020401/ Retrieved on: Sep. 19, 2020

16. J. Kim, R. G. Moreira, M. E. Castell-Perez, "Validation of irradiation of broccoli with a $10 \mathrm{MeV}$ electron beam accelerator," J. Food Eng., vol. 86, no. 4, pp. $595-603$, Jun. 2008. DOI:10.1016/j.jfoodeng.2007.11.018

17. H. Qin et al., "Concept development of X-ray mass thickness detection for irradiated items upon electron beam irradiation processing," Radiat. Phys. Chem., vol. 143, pp. 8 - 13, Feb. 2018. DOI: 10.1016/j.radphyschem.2017.09.012

18. J. Kim, R. G. Moreira, M. E. Castell-Perez, "Improving phytosanitary irradiation treatment of mangoes using Monte Carlo simulation," J. Food Eng., vol. 149, pp. 137 - 143, Mar. 2015. DOI: 10.1016/j.jfoodeng.2014.10.005

19. I. Peivaste, Gh. Alahyarizadeh, "Comparative Study on Absorbed Dose Distribution of Potato and Onion in Xray and Electron Beam System by MCNPX2.6 Code," $M A P A N$, vol. 34, no. 1, pp. 19 - 29, Mar. 2019. DOI: $10.1007 / \mathrm{s} 12647-018-0287-\mathrm{z}$

20. V. I. Shvedunov et al., "Electron accelerators design and construction at Lomonosov Moscow State University," Radiat. Phys. Chem., vol. 159, pp. 95 - 100, Jun. 2019. DOI: 10.1016/j.radphyschem.2019.02.044

21. J. Allison et al., "Recent developments in GEANT4," Nucl. Instrum. Methods. Phys. Res. A, vol. 835, pp. 186 - 225, Nov. 2016. DOI: 10.1016/j.nima.2016.06.125

22. U.A. Bliznyuk et al., "Computer simulation to determine food irradiation dose levels," IOP Conf. Ser.: Earth Environ. Sci., vol. 365, article no. 012002, 2019. DOI: 10.1088/1755-1315/365/1/012002 